\title{
Lo que a nadie asusta pero a todos preocupa. Etnografía de los miedos cotidianos en una comunidad del altiplano sur boliviano
}

\author{
What Scares Anyone but to all Concern. \\ Ethnography of Everyday Fears in a Southern Bolivian \\ Highlands Community
}

Francisco M. Gil García

Dpto. de Historia de América II (Antropología de América) Universidad Complutense de Madrid

\section{RESUMEN}

Partiendo de la idea de que el miedo existe instalado en nuestras vidas, se analiza el doble discurso de miedos negados y preocupaciones reconocidas desde el que los habitantes de una comunidad del altiplano boliviano explican su vida cotidiana, prestando especial atención a las razones esgrimidas por los adultos en la educación de los niños a la hora de prohibirles frecuentar determinados ambientes o realizar en ellos ciertas acciones. Para ello partiré de una distinción espacial dentro del entramado urbano, diferenciando así entre espacios propios, seguros y reconocidos - pero potencialmente amenazados- que, debido a la concurrencia de determinadas alteridades terribles presentes y pretéritas, son sentidos como un territorio de los otros, una geografía atemorizadora donde suceden cosas, escenarios del miedo que necesitan ser conjurados y reordenados.

Palabras clave: Miedo, Espacio social, Vida cotidiana, Nor Lípez, Potosí, Bolivia.

\section{SUMMARY}

From the idea that fear is installed in our lives, I analyze the double talk of fears denied and concerns recognized from which the inhabitants of a community in the Bolivian high-plateau explain their daily lives, paying particular attention to the reasons given by adults in the education of children when being in certain environments or forbid them to perform certain actions. So, I will present a spatial distinction among urban settings: the own spaces, secure and recognized - but potentially threatened-, and the territory of the others, which the concurrency of past and present terrible otherness transforms in a frightening geography where things happen, fear scenarios that need to be conspirators and reordered.

Key words: Fear, Social Space, Everyday Life, Nor Lípez, Potosí, Bolivia. 
La Modernidad educa a sus hijos en la ausencia del miedo, y Ciencia y Razón se empeñan en imponernos la idea de que el ser humano domina el Mundo, relegando así a nuestros miedos primarios (la furia de los elementos, la oscuridad, la enfermedad, la violencia, los muertos, lo desconocido, los monstruos, el otro...) a la condición de sinsentidos o supercherías. Y sin embargo es precisamente del seno de ese mundo global en que vivimos, sobreindustrializado y sobretecnificado, de donde diariamente emergen nuevos miedos; nombrarlos implica, como apunta R. Reguillo (2006: 25), captar su emergencia, hacer hablar a los miedos antiguos en lenguajes contemporáneos y obligar a los miedos nuevos a inventar su propio modo de hablar de sí mismos. Este hecho de permanentemente reinventar viejos peligros e inventar nuevas amenazas es lo que lleva a J. A. Marina (2006: 13) a resolver que vivimos "confundiendo realidad con irrealidad, es decir, hechos un lío". Una confusión, por otra parte, a la que contribuye el hecho de que la mayor parte de esos desasosiegos son silenciados públicamente e incluso negados, tanto por el individuo que los experimenta como por la sociedad que los construye y la cultura que los comparte. Sin embargo, viejos y nuevos temores están ahí, porque, como suele decirse, el miedo es libre, y cada cual, en lo más hondo de su ser, alberga sus propios miedos. Miedos soterrados, a veces ignorados por nuestro consciente, muchas veces disimulados, generalmente no reconocidos, casi siempre por vergüenza. Negamos el miedo y por arte de birlibirloque lo transformamos en preocupación, recelo, cuidado, aprensión, sospecha... Es lo mismo, pero no es igual; lo hemos "domesticado".

Sin embargo, aquella Modernidad en la que supuestamente vivíamos felices entró en crisis un día; otra vez más se voltearon los esquemas de organización social, se trastocaron los sistemas simbólicos y se desestructuraron los principios de (auto)representación colectiva, generándose así diversas dinámicas de (re)invención de las tradiciones y (re)construcción de las identidades. Crisis de la Modernidad, advenimiento de una Postmodernidad tan poliédrica como polivalente, y revitalización de "lo tradicional". Sin embargo, como consecuencia del largo e intrincado proceso de resemantización de los sistemas culturales, los valores tradicionales de hoy son ya otros, las costumbres se han relajado y la Tradición se reduce fundamentalmente a un folklore que muchos - quienes no entienden que la Cultura está viva- desprecian por sincrético, hibridado, mestizo e incluso kistch. Las utopías de progreso y desarrollo barren esos saberes populares que, pese a todo, sobreviven al envite refugiados en mitos y cuentos, cosas de los abuelos que, como señala L. Díaz (2003: 158), mantienen latente "lo que la creación popular es capaz de decir en ese su sin saber sabiendo".

Desde estos presupuestos, mi propósito en las páginas que siguen será el de analizar cómo lo tradicional y lo moderno se fusionan en la resemantización de los objetos y los espacios del miedo dentro de una comunidad del altiplano sur boliviano, intentando con ello descifrar una dialéctica de contradicciones entre el poso ideológico de unos miedos ancestrales negados y la práctica cotidiana donde tales temores han quedado revestidos de banalidad, "Sentido común" o monstruos simpáticos. En trabajos anteriores ya reflexioné sobre esta cuestión al tratar el modo en que los ideales de progreso se imponen al miedo a la hora de que las propias comunidades gestionen sus ruinas arqueológicas (Gil 2006), y evoqué la imagen de una comunidad sitiada al componer una suerte de atlas cultural de los escenarios del miedo y las entidades terribles a partir de las cuales se fijan sus límites dentro del orden social (Gil 2008). 
En esta ocasión mi interés se fija en ese doble discurso de miedos negados y preocupaciones reconocidas desde el que los habitantes de la comunidad de Santiago "K" (Nor Lípez, Dpto. de Potosí) ${ }^{1}$ explican su día a día, prestando especial atención a las razones esgrimidas por los adultos en la educación de los niños a la hora de prohibirles frecuentar determinados ambientes o realizar en ellos determinadas acciones. Para ello partiré de una distinción espacial dentro del entramado urbano, diferenciando así entre un "espacio tópico" (propio, seguro, reconocido... pero potencialmente amenazado) que, debido a la concurrencia de determinadas alteridades terribles presentes y pretéritas, es sentido como un "espacio heterotópico" (el territorio de los otros, una geografía atemorizante donde suceden cosas... escenarios del miedo ${ }^{2}$ ) que necesita ser conjurado, reordenado. En este punto, como veremos, es donde el discurso oficial y las prácticas cotidianas entran en conflicto, poniendo en práctica aquella máxima de "donde dije digo, digo Diego".

\section{LA COMUNIDAD SITIADA}

La comunidad de Santiago se ubica al sur del Salar de Uyuni, a 3.800 m.s.n.m. en el extremo norte del Altiplano de Lípez, descrito habitualmente como la parte fértil de una región considerada la más árida del país a consecuencia de su extrema sequedad y sus bajas temperaturas. Con aproximadamente 80 familias (600-650 habitantes censados), en Santiago abundan los niños y los adolescentes (más de un cuarto de la población total), y faltan los jóvenes, que suelen emigrar temporalmente para seguir sus estudios o para buscar trabajo, a Uyuni, Potosí, Oruro, La Paz o al vecino Chile.

Los santiagueños se sienten precisamente eso: santiagueños. No exaltan una identidad indígena u originaria, y tampoco la reivindican. No se dicen campesinos, aunque cultivan la tierra; ni pastores, aunque crían ganado, fundamentalmente llamas. Mayoritariamente hablan en español, mantenido el quechua por la gente de más edad (monolingües las mujeres, bilingües los hombres), conocido por la población de mediana edad y casi perdido entre jóvenes y niños a pesar de los empeños del ViceMinisterio de Cultura de Potosí por alcanzar una educación bilingüe; el quechua queda reservado para algunas fórmulas y letanías en los costumbres (rituales), para la conversación reverencial con los ancianos o para esa intimidad doméstica donde la presencia de un antropólogo puede llegar a resultar incómoda.

\footnotetext{
${ }^{1}$ Pudiera pensar algún lector que, siguiendo una práctica frecuente en algunas etnografías clásicas, se está enmascarando aquí el nombre de la comunidad de Santiago "K", cuando en realidad se trata de éste: la letra "K" responde a una antigua demarcación cantonal hoy en desuso, aunque mantenida todavía en algunos topónimos de la provincia de Nor Lípez como parte incorporada a los mismos. Sin embargo, los santiagueños sólo utilizan el nombre completo a efectos oficiales, y ocasionalmente para diferenciar a su comunidad de la vecina Santiago Chuvica. De esta manera, siguiendo los usos de la toponimia local, y a efectos prácticos de escritura y lectura, en lo sucesivo emplearé el nombre corto de comunidad de Santiago.

${ }^{2}$ Tomo ambos conceptos de los trabajos de Reguillo (2000, 2006) sobre la espacialidad de los miedos contemporáneos en la ciudad, las mitologías urbanas y la construcción social del miedo desde el estudio de las narrativas utópicas que, soterrando la base real del miedo, tratan de maquillarlo a partir de prácticas cotidianas de carácter cuasi propiciatorio que permitan esquivar tales espacios y/o enfrentarse con las alteridades terribles que los pueblan.
} 
Como ya mencioné en otro lugar (Gil 2008: 147), podría decirse que Santiago no es una comunidad exótica, que allí nunca pasa nada; o más bien se dice que no pasa, o se actúa como si no pasara, y me parece que es ahí donde precisamente radica el interés de esta comunidad para la antropología ${ }^{3}$. En realidad, más allá del discurso mitohistórico oficial, y aplicando tesón, paciencia y picardía al preguntar, en Santiago pasan muchas cosas. Pasan, aunque todo pareciera apuntar a que más bien pasaban; esas otras cosas pasaban "cuando los abuelos", "más antes", "cuando los antiguos", "en otro tiempo"... "Y así no más. Eso es todo", que suelen decir los santiagueños para zanjar la cuestión cuando la conversación empieza a incomodarles.

"Cuentitos que me sabían contar cuando era niño. ¡Quién los va a creer!", como me dijo una vez en 2002 Erasmo Condori Ticona (60 años $\left.{ }^{4}\right)$, a quien presentaré más adelante. Cuentos que a mí como etnógrafo siempre me interesaron, por su valor testimonial de esos saberes soterrados. Cuentos que, lamentablemente, se están perdiendo, pero a los que es posible llegar cuando uno se aplica en la observación y la lectura entre líneas de los actos y los modos cotidianos de los santiagueños. Y llegado este punto se me permitirá un paréntesis para definir los escenarios donde se desarrolla el día a día de la comunidad, pues ello ayudará a fijar los límites de un espacio social (culturizado, civilizado) al borde del cual acechan esos miedos que, en suma, constituyen el interés de este trabajo.

En términos espaciales, Santiago es un pueblo aprisionado en y por su propio entorno, ubicado en la hoyada que se forma entre los cerros Qaral (al oeste) y Lliphi (al este), sobre el piedemonte del primero, que lo cierra también por el noreste; ahí, sobre la colina, se levanta un santuario al Señor de Quillacas al que luego me referiré. De oeste a este, una torrentera seca (wayco) que baja desde la falda del Qaral divide el trazado urbano en dos mitades, que llaman el Pueblo Viejo y el Pueblo Nuevo. En el primero, más antiguo, con casas predominantemente de piedra y algunas calles empedradas, se emplazan la iglesia, el Corregimiento y el Cabildo, la plaza con su quiosco para música, la parada de la ruta (el autobús de línea), el "motor de la luz" ${ }^{5}$ y doce calvarios repartidos entre el atrio de la iglesia y la pampa frente a ella, la plaza del Cabildo y algunos cruces de calles. En la parte nueva, con casas predominantemente de adobe con techo de calamina, se ubican los distintos edificios del Núcleo Educativo "Miguel Cuzco" y las canchas deportivas, la posta sanitaria, dos calvarios —en una de las salidas del pueblo- y el cementerio, que por efecto

${ }^{3}$ Señalaba C. Bernand (1986: 8) en la introducción a su monografía sobre los renacientes de Pindilig (Ecuador) que aquel "no es un pueblo exótico, pero su interés reside justamente en su banalidad aparente; los indígenas hablan en castellano, y no por ello lo que dicen carece de importancia para la antropología. [...]. Nadie en el pueblo elucubraba sobre astros ni ritos antiguos. Interrogar a la gente sobre tales temas creaba una situación artificial y aportaba información desprovista de savia". Con su permiso y con el de aquellos, estas mismas palabras, más o menos matizadas, se ajustan perfectamente a la comunidad de Santiago, a sus gentes y la cotidianidad de mi trabajo de campo etnográfico entre ellas.

${ }^{4}$ Las edades indicadas corresponden a la que las personas citadas tenían al tiempo de ofrecerme su testimonio, indicada esta fecha bien en su presentación, bien al final del mismo.

5 A Santiago no llega tendido eléctrico, existiendo un motor de gasoil ("el motor de la luz", o sencillamente "el motor") que al caer el sol abastece a los hogares de corriente durante dos horas cada día. El control de su encendido y apagado está entre las funciones del Corregidor, y el combustible se paga entre toda la comunidad a partes iguales. 
de la expansión urbanística ha quedado prácticamente adosado a la comunidad. Al este, en la confluencia de las vertientes de los cerros, Agua de Castilla, un curso de agua estacional. Entre el borde oriental del pueblo (iglesia - "motor de la luz" - posta sanitaria - campo de fútbol - cementerio) y este cauce se reparten algunas estructuras chullparias ${ }^{6}$ desperdigadas que se multiplican a medida que se empieza a ascender por las faldas del Lliphi.

Inserto en este paisaje, sólo el casco urbano de Santiago constituye un lugar seguro, donde imperan unas reglas de conducta civilizada y donde la unión de los comunarios actúa como fuerza protectora; la vida en sociedad garantiza seguridad y protección frente a los peligros que llegan de fuera. Por el contrario, los cerros constituyen un espacio salvaje, más cuanto más alta sea la cota que ascendamos, domesticados sólo en parte por la presencia de chacras (parcelas) para el cultivo de papas. Salvaje es también el espacio ocupado por los yacimientos arqueológicos ubicados en las faldas de ambos cerros, donde habitan los chullpas, los gentiles. Pero también es salvaje esa torrentera seca que baja del Qaral y que divide a la comunidad, donde se acumulan basuras y donde a veces las lluvias dejan al descubierto huesos y objetos de los antiguos. También Agua de Castilla y el espacio más allá de este cauce, quizás el límite más evidente del espacio social de la comunidad de Santiago. Salvajes son también las inmediaciones del santuario del Señor de Quillacas, por los poderes que allá se concentran. Salvaje es la pampa que se extiende entre el borde oriental del pueblo y Agua de Castilla, donde se yerguen algunas estructuras chullparias y por donde campa el condenado. En parte salvaje es el cementerio, por algo que luego comentaré. Salvaje es, por último, cualquier espacio más allá de las últimas casas del pueblo en dirección sur-sureste, saliendo por los caminos que llevan hasta la comunidad vecina de San Juan y que siguen dirección a Uyuni. Espacios salvajes todos ellos, sin embargo, donde a los niños les gusta ir a jugar. Espacios infantiles de juegos que para los adolescentes constituyen escenarios de miedos negados, y donde los adultos prefieren disfrazar sus miedos bajo el manto de otros peligros más mundanos.

En suma, todo lo que habite en estos límites o que venga de más allá sería susceptible de considerarse un peligro potencial, un miedo que hay que imprimir a esos niños que, víctimas de su propia curiosidad, son propensos a sucumbir a "los encantos" del forastero. (¿A quién de nosotros no machacaron con aquello de "no te vayas con extraños" y "no aceptes regalos de extraños»?). La gente de las comunidades vecinas es peligrosa, y al conversar con ellos no hay que darles mucha información porque nunca se sabe para qué puedan utilizarla después. Mucho más peligroso es el turista, que además suele llegar a las comunidades cerca de la anochecida, para descansar en su recorrido por el altiplano. A fines de agosto de 2001 yo mismo llegué junto con algunos turistas a Jirira, al norte del Salar de Uyuni, a la sombra del volcán Tunupa. Llegamos cansados y salimos a estirar las piernas mientras prepara-

\footnotetext{
${ }^{6}$ En arqueología andina se denomina estructura chullparia, chullpa o torre-chullpa a un tipo de monumento funerario torriforme, de planta redonda o cuadrada, construido en piedra o adobe, propio del altiplano centro-surandino de los Desarrollos Regionales del Período Tardío (siglos X-XV), cuya construcción se mantuvo durante época Inca y su reutilización incluso en los primeros tiempos de la Colonia.
} 
ban nuestro acomodo y nuestra cena. Apenas había gente por las calles del pueblo, pero sí recuerdo a un grupo de niños — quizás de no más de siete años- que apuraban sus últimas horas de juego. Como siempre en estos casos, alguien sacó del bolsillo caramelos, a lo que siguió alguna broma, unas cosquillas. Sin saber de dónde salieron, no tardaron en aparecer otros niños más mayores (¿sus hermanos?) que los apartaron de nosotros a tirones y empujones, regañándoles, algún capón incluido. Para decepción del miedo, siempre hay alguien vigilando.

Un comportamiento similar lo presencié en Santiago en septiembre de 2002, a plena luz del día. Una tarde, en plena ebullición de niños jugando en la calle tras la jornada escolar, apareció un vehículo de turistas del que bajaron unos gringos, cámara de fotos en mano y repartiendo caramelos y globos. Lo que pasó a continuación puede resumirse en tres movimientos. Primero, los niños se arremolinaron en torno a los recién llegados. Segundo, algunas madres acudieron a dispersar a la chiquillería. Tercero, madres y niños desaparecieron, pasando un buen rato desde que el vehículo de turistas se marchara hasta que la calle empezó tímidamente a ser ocupada de nuevo por los niños. A la noche comenté lo sucedido con mi comadre Eva Quispe Cayo (35 años), madre de cinco hijos — seis a día de hoy-. "Nunca sabes. Que se te llevan a los niños, dicen. Ellos se acercan no más de puro curiosos, y ahí te les agarran. Desaparecen y ya no les ves nunca más. Dicen que pasa eso", me comentó ella con una seriedad disimulada. Quizás lo que más teme cualquier madre, que le roben a sus hijos.

Hasta aquí todo podría ser "normal", y el recelo que los santiagueños sienten por sus vecinos y el miedo que despiertan en ellos los forasteros y los turistas no tendrían nada de particular. Sin embargo, Santiago es una comunidad sitiada por otros enemigos si cabe mucho más peligrosos: seres que no son de carne y hueso, que no son humanos, o al menos no del todo, manifestaciones de una alteridad "sobrenatural" más o menos extrema, entidades terribles que causan enfermedad, inflingen daños físicos y acosan a sus víctimas hasta la muerte. Antes se creía más ellos, y ahora se los trata de ignorar como si de ese modo dejaran de suponer un riesgo para los comunarios. De todos modos, ahí siguen, ocupando los mismos escenarios del miedo que siempre ocuparon, aunque ahora estos espacios se quieran ver desde otro prisma. Vayamos por partes.

\section{A NIÑOS IGNORANTES, PADRES ACECHANTES}

Como en tantos otros entornos rurales, los niños de Santiago se crían en la calle, aparentemente desatendidos de sus padres, aún cuando esta observación resulte del todo falsa. Es cierto que campan a sus anchas por la comunidad y su entorno más próximo, pero también que en alguna parte hay casi siempre una mirada adulta que los vigila; cualquiera, aunque no sea de la familia; primero porque aquí al adulto todavía se le respeta, y segundo porque en un pueblo chico es difícil pasar desapercibido. Lo he presenciado muchas veces. Madres que saben perfectamente dónde están sus hijos aunque aparentemente los tengan desatendidos. Vecinos que al cruzarse se dan el parte de novedades, o que acuden a casa a devolver a sus padres al niño que se cayó, al que se peleó con otro, al que sorprendieron haciendo travesuras, al 
que recogieron de donde no debía estar o simplemente porque ya es hora de volver. Cuando no, generalmente los padres saben muy bien dónde buscar a sus hijos, porque los escenarios de juego habituales son los que son y no hay más opciones en la comunidad, quizás porque ellos una vez también fueron niños y se sintieron atraídos por esos mismos lugares.

Por supuesto, a veces padres e hijos se despistan, y entonces cunde la preocupación. Recuerdo por ejemplo una tarde de noviembre de 2004 en la que dos de los hijos más pequeños de mis compadres Justino Calcina Lupa (43 años) y Eva Quispe Cayo (38 años) no regresaban a casa. Se hizo de noche, todo el pueblo estaba ya en sus casas y estos dos seguían sin aparecer, ante lo cual sus padres empezaron a preocuparse de verdad. Salieron en su busca, preguntaron a los vecinos, a los otros niños, pero nada. El motor eléctrico dejó de funcionar, era noche cerrada, ya pasaban de las nueve y entonces fue cuando aparecieron. Habían estado toda la tarde jugando en casa de un amiguito, donde aprovechando las horas de luz habían disfrutado de un video de Cantinflas; al cortarse la luz y quedarse sin película, regresaron a casa, ignorantes de la preocupación del resto de la familia. Preocupación, por otra parte, lógica y razonable: han sufrido algún accidente, se han alejado demasiado y no saben volver, de puro cansancio se han quedado dormidos por ahí. Pero en un momento dado afloró otro tipo de miedo: a su madre le inquietaba el hecho de precisamente aquella era una noche ventosa, y eso los podía hacer enfermar. No es que los niños pudieran resfriarse — según mis diarios, ingenuo de mí, traté de tranquilizarla recordando que habían salido de casa bien abrigados-, sino porque dentro de la concepción indígena de los fenómenos naturales, existen buenos y malos vientos, vientos que pueden hacer enfermar, que agarran, que asustan, que se llevan una parte de la esencia anímica del sujeto ${ }^{7}$. He ahí el quid de la cuestión. Evidentemente, los progenitores estaban inquietos ante un abanico de posibles situaciones de riesgo "razonables", pero también estaban asustados ante otra probable amenaza "imaginaria" que resultaba velada. Cada vez que en los días sucesivos traté de indagar sobre los peligros del viento siempre topé con negativas o respuestas evasivas: ¿¿qué daño puede hacernos un mal aire si no es el de causarnos un resfriado?!

Hablando de niños ignorantes de esas amenazas "sobrenaturales" que acechan en las fronteras del espacio social de Santiago, dos son los escenarios a los que habrá que acudir sin remedio: el wayco que divide la comunidad en dos y la pampa que se extiende en torno al motor y la posta sanitaria, dos lugares que tanto o más "atraen" a los niños como "preocupan" a los adultos.

Como en más de una ocasión me comentaron los pequeños, se trata de escenarios donde se pueden encontrar cosas (bolígrafos, rotuladores, papeles, cajitas, juguetes rotos, etc. que aparecen entre la basura desperdigada), donde hay ceniza con la que jugar a empolvarse la cara y las manos, donde a veces aparecen huesos -de fauna actual, pero también de animales y humanos de otros tiempos-. Para sus padres, sin embargo, son precisamente tan atrayentes hallazgos lo que constituye un peligro:

\footnotetext{
7 A diferencia del concepto monolítico de alma cristiana, los pueblos andinos conciben el concepto de persona como la unión indisoluble de un cuerpo y tres esencias anímicas o sombras, dobles de su propietario que recibirán diferente nombre según regiones y pueblos; de la integridad de cuerpo y "almas" depende la salud del sujeto.
} 
basura y por ende peligro de enfermedades, hierros y cristales que pueden cortar o pinchar, cenizas que ensucian el cuerpo y la ropa; en torno a la posta sanitaria, además, envases de medicamentos, cristales, alguna aguja. Hasta aquí, todo resulta perfectamente entendible, y ninguno de nosotros dejaría a sus hijos "jugar" en un basural. Pero hay más. A estos motivos de preocupación adulta han de añadirse una serie de temores encarnados en la figura de dos de esas entidades terribles que acechan a la comunidad: los chullpas y el condenado, a los que nadie tiene miedo, pero que a todos, antes o después, en mayor o menor grado, asustan.

Los chullpas o antiguos no son otros que los gentiles, enanos taumaturgos habitantes de aquella Edad presolar en la que, bajo el signo de la Luna, imperaba el caos, la idolatría, la guerra del todos contra todos, el canibalismo; un tiempo habitado por gentes sin civilizar y que no eran cristianas, de las que, desde luego, los santiagueños no se sienten en absoluto herederos. Murieron abrasados por el Sol primigenio, y su tiempo quedó congelado en los sitios arqueológicos, donde hoy podemos encontrar sus cuerpos desecados y los vestigios materiales de su cultura ${ }^{8}$. Por eso las ruinas son un lugar peligroso al que, en todo caso, habrá que aproximarse con respeto, para no molestar a los chullpas. Dicen - y entonces por algo será- que no se puede acudir a su entorno para jugar ni para armar jaleo, que no se pueden levantar y llevar los objetos arqueológicos, que no está bien convertirlas en basurero ni en espacio para hacer las necesidades, y desde luego no es ni por asomo el sitio indicado para que los jóvenes den rienda suelta a sus pasiones. Todo ello molesta a los chullpas, seres irritables que agarrarán al incauto y lo harán enfermar, puede incluso que hasta la muerte?

En cierta ocasión recorrí las cercanas ruinas de Laqaya ${ }^{10}$ con mi compadre Justino. Él me iba explicando las particularidades del sitio arqueológico, y me comentó una anécdota que creo viene a colación:

Las puertas están vistas a un solo lado, y hay como unos laberintos, calles muy chiquititas que es... Bueno, sirven como pa' perderse ¿no? Cuando yo estaba chico vine a pastear ovejas, y me entré ahí, pero nunca pude salir... y bueno, jasí llorando salí! Qué cosas. Por ahí no estaba sólo, ¿verdad? [risas]. (Justino Calcina Lupa, 41 años. Laqaya —Santiago-, 15/09/2002).

Se conoce el peligro, se sabe a qué debe temerse, pero se ignora e incluso se ridiculiza ese miedo tradicional a los chullpas ("Qué cosas!", dice Justino, y se ríe de

\footnotetext{
${ }^{8}$ Para un mayor detalle sobre el tiempo de los chullpas a partir de la tradición oral que en Santiago cuentan sobre sus ruinas (Cfr. Gil 2005).

9 Con variantes, la enfermedad de los chullpas consiste en que el afectado pierde el ánimo, las ganas de comer, va entrando en un estado de apatía y enflaquece sin remedio, como si el chullpa estuviera chupando la fuerza vital del enfermo para nutrir su cuerpo reseco y abrasado. Por eso el especialista ritual deberá actuar rápido, ofreciendo a esta entidad tutelar una "comida" ( $m e s a$ de ofrendas) lo suficientemente apetitosa como para que suelte a su presa humana.

${ }^{10}$ Laqaya (del quechua, pueblo en ruinas), con sus 7 ha., es quizás el yacimiento arqueológico por antonomasia de todos los que rodean la comunidad de Santiago, y aquel del que se sienten más orgullosos, pues no en vano lo consideran la capital de Lípez en el tiempo de los chullpas. En él ponen buena parte de sus expectativas de futuro como comunidad, y desde hace más de una década, en estrecha colaboración con arqueólogos y con el vecino pueblo de Santiago Chuvica, se vienen realizando trabajos de acondicionamiento y puesta en valor que han permitido su calificación como Monumento Histórico (octubre de 2004) y su inclusión en los circuitos turísticos que cruzan el Salar de Uyuni en dirección a San Pedro de Atacama.
} 
sí mismo por pensar en ello). Y es que hoy en día la concepción de las ruinas ha cambiado (Gil 2006); de espacio del miedo se han transformado en valor patrimonial de interés turístico. Llegan los arqueólogos, los turistas, los gringos, pasean por entre sus muros, hurgan en la tierra, sacan objetos y no les pasa nada. Los comunarios les ayudan en los trabajos arqueológicos y tampoco pasa nada. Por todo ello, a priori, la gente ha dejado de temer a los chullpas, o eso dicen. Volveré sobre ello en seguida, aunque ahora sigamos con esos niños que gustan de jugar en el cauce seco de la torrentera.

Como decía, en el wayco aparecen a veces restos óseos que la gente suele asociar a los chullpas, y que por tanto resultan un peligro en potencia. Pero los niños, quizás también movidos por una curiosidad morbosa, puede que jugueteen con ellos y pongan en riesgo su salud, o incluso que los lleven a otra parte, causando entonces apuro a otras personas. Visto así, ¿a qué temen más los padres de esos niños que acuden a esta torrentera, a las amenazas físicas revueltas entre la basura o a los amenazantes chullpas?

Muchas veces he visto a madres enojadas con sus pequeños al verlos aparecer en casa manchados de cenizas o portando alguna porquería encontrada en la basura, sacudiéndoles el polvo y de paso los cachetes. Sin embargo - y a diferencia de lo que tal vez pudiéramos pensar-, no es habitual que se asuste a los niños pequeños con los chullpas, con amenazas del tipo el chullpa se lleva a los niños malos o el chullpa te va a agarrar. A fin de cuentas, no habitan el mismo plano espacio-temporal en el que viven los santiagueños, pues su presencia está reducida al espacio de las ruinas y su esencia al de los hallazgos arqueológicos; a diferencia de otras entidades tutelares, no son ellos quienes andan en nuestra busca, sino que más bien reaccionan en nuestra contra cuando nosotros les importunamos. Con todo, su recuerdo sí se mantiene vivo, o mejor dicho, el recuerdo de su manera de ser salvaje, especialmente en sus hábitos culinarios: además de ser caníbales, los chullpas comen sin sal y sin azúcar ${ }^{11}$. Cuántas veces he tenido que oír de boca de niños eso de "mira, como chullpa toma", porque gusto del té sin azúcar, al contrario de su costumbre de endulzar en exceso el té o la leche y de añadir incluso azúcar a los refrescos - motivo éste de reproche por parte de sus padres-. Sin embargo, cuando en 2004 a los pequeños Adrián y Damiana ( 5 y casi 4 años respectivamente) les dio por imitarme en esto de no endulzar su té, eran sus padres, Justino y Eva, quienes se lo añadían sin que ellos se dieran cuenta; "porque es bueno para que los chicos crezcan sanos", decían, y también, añado yo, porque así es como un cristiano ha de tomar su té. Con todo, y a pesar de lo dicho, sí escuché muchas veces a mi comadre amenazar a los pequeños con que si no terminaban de comer, o si no comían tal o cual alimento, se volverían chullpas. Ahora bien, esta transformación no tiene tanto que ver con una metamorfosis del niño en chullpa, como con una evocación de las momias que aparecen en los enterramientos arqueológicos: así como los chullpas abrasados por los rayos del Sol primigenio quedaron reducidos a huesos y piel seca, así, delgados y escuchimizados, se quedarían ellos de no alimentarse debidamente. En este sentido, resulta significativo que Eva instase a Adrián

\footnotetext{
${ }^{11}$ En términos generales, lo que los chullpas no hacen es condimentar su comida, por eso no toman ni sal, ni azúcar, ni ají. Esto es precisamente lo que les diferencia de los cristianos (los humanos), y lo que marca su grado de salvajismo.
} 
a comer cebolla ${ }^{12}$ para no volverse chullpa, pues éste es otro de los alimentos que los cuentos mencionan como ausente en la dieta de los chullpas (Gil 2014). Interrogada mi comadre sobre esta cuestión, ella, poco dada a hablar de estas cosas, siempre me contestaba lo mismo: que al chico no hay manera de hacerle comer cebolla, y ni asustándole se consigue que la pruebe.

A diferencia del wayco, donde la eventual aparición de esos restos óseos de dudosa procedencia remite a la presencia de los chullpas, para el caso de la pampa que se extiende entre el cauce de Agua de Castilla y el borde oriental de la comunidad resulta más difícil destapar esos miedos tradicionales que la convierten en un lugar poco recomendable para los juegos infantiles; e incluso para el trasiego de los adultos una vez caída la noche. Aparte de las razones higiénico-sanitarias antes señaladas, sobre ella pesan otros miedos, acechan otros peligros. Vayamos por partes, sin despistar nuestra atención de los más pequeños.

Quizás por su inocencia y su curiosidad, los niños suelen resultar pieza clave del trabajo de campo del etnógrafo; al menos hasta entrar en la adolescencia, ni sienten vergüenza ni autocensuran su discurso, por lo que conversar con y dejarse guiar por ellos suele reportar interesantes "descubrimientos" sobre los cuales profundizar después en la entrevista con los adultos. Gracias a los niños, por ejemplo, supe durante mis primeros días en Santiago - a fines de agosto de 2001- que como parte de algunas celebraciones rituales se ch $^{\prime}$ alla $^{13}$ la torre campanario de la iglesia se rociaba con sangre de los animales sacrificados mezclada con hojas de coca, mientras que los adultos no me revelaron el detalle hasta mucho tiempo después — ¿Esa sangre?... Será que se estrelló algún pájaro contra la torre", me respondió alguien entre risas cuando pregunte a los entendidos de la comunidad-. También fueron ellos quienes primero me mostraron el lugar pegado al muro perimetral de la iglesia donde se ofrecen los pagos andinos durante la festividad del Patrón Santiago: un pocito de ofrendas tapado con una laja de piedra grande, que ellos a veces levantan por curiosidad, llegando incluso a enredar con los restos de ofrendas todavía presentes, sin saber que eso no debe hacerse para no molestar a la entidad tutelar a la que fueron elevadas ${ }^{14}$.

También en esta pampa se emplazan algunas estructuras chullparias, que se multiplican más allá de Agua de Castilla, en el piedemonte del cerro Lliphi, con los riesgos implícitos que ya he mencionado.

${ }^{12}$ Dentro de la gastronomía local, la cebolla generalmente se añade a la sopa para que hierba, o se sirve cruda como acompañamiento de los platos de arroz o, cuando se consiguen hortalizas, formando parte de la ensalada.

${ }^{13}$ En quechua y aymara, v. ch'allar, s. ch'alla: Aspersión o libación que se efectúa en todo acto ritual/ceremonial andino, destinada a agradar a las entidades tutelares y/o a marcar los espacios ceremoniales, ya sea con alcohol puro, vino, cerveza, agua de vertientes o la sangre del animal sacrificado. Según contextos, la ch'alla puede operar también a modo de consagración de la acción ritual en su conjunto.

${ }^{14}$ La plaza principal de la comunidad, con su quiosco para música, queda delimitada por el Cabildo y la iglesia, y en ella es frecuente — sobre todo en la hora de los recreos escolares y a la tarde- que se reúnan los niños a jugar; a veces se cuelan en el recinto de la iglesia y ello les supone una regañina por parte de los adultos. Cuando volví a Santiago en noviembre de 2004 habían puesto puertas metálicas a este recinto, antes siempre abierto. Me dijeron que porque estaban empezando a llegar más turistas, que entraban sin permiso y sin guardar el debido respeto, pero una profesora de la escuela me comentó que así también podían despreocuparse de los niños, que ya sabe usted que se metían a jugar y a veces hacían desastre por no saber. 
Pero quizás el mayor peligro que acecha en este espacio abierto sea la figura de el condenado, personaje sobre el que volveré enseguida, después de profundizar un poco más en las actitudes cotidianas respecto de estas chullpas y otras ruinas arqueológicas.

\section{APARIENCIAS MANTENIDAS, PRECAUCIONES GUARDADAS}

Desde que llegué a Santiago por primera vez en 2001, siempre me he alojado en casa de los que acabarían convirtiéndose en mis compadres Justino y Eva. Durante mi primera estadía, Gonzalo, el hijo mayor (13 años entonces), me acompañó en muchos de mis paseos arqueológicos por las inmediaciones de la comunidad. Pese a ser un muchacho callado, en ocasiones me contaba alguna historia, algún chisme; otras veces me ayudaba a sujetar el flexómetro que yo utilizaba de guía en la fotografía de las estructuras chullparias. Siempre que le pregunté si esta tarea le incomodaba, siempre me respondió que no; cada vez que le insinuaba si las chullpas le daban miedo, su respuesta era la misma: que no. Él aguantaba paciente el flexómetro mientras que yo enfocaba y disparaba, pero al cabo de unas cuantas fotografías observé que siempre lo sujetaba de lejos, sin arrimarse a las estructuras. Cuando le hice partícipe de esta observación, sonrió y sencillamente cambió de tema. Insistiéndole recurrentemente en esta pregunta, unas veces me respondía que era por si yo no quería que él saliera en la foto, otras que porque por lo accidentado del terreno no podía acercarse más, otras que por si se arrimaba demasiado y dañaba las estructuras... Al cabo yo dejé de preguntarle.

Todos hemos pasado por esa edad, en la que ya no nos sentimos niños pero los adultos todavía no dejan de considerarnos como tales; una edad, más o menos y según cada cual, en la que todos los chicos nos hemos hecho los "machitos", disimulando el miedo aún cuando lo tuviéramos y burlándonos de aquel que lo exteriorizaba. Así, Gonzalo y sus amigos muchas veces ponían a prueba mi coraje, aunque en realidad eran estos pulsos los que, en el trabajo de campo, me servían a mí para poner a prueba sus valores, sus miedos. Y muchas veces con las ruinas arqueológicas y los chullpas como telón de fondo.

Es una creencia extendida en los Andes que estos antiguos guardan tesoros prehispánicos, el oro de las wakas, el llamado oro vivo, haciendo enfermar a quien osa hurgar en las ruinas buscando objetos arqueológicos y más concretamente riquezas. En una ocasión, recorriendo las mencionadas ruinas de Laqaya con Gonzalo, yo alcé unas puntitas de flecha. "No vas llevar, ¿verdad?", me preguntó él, a lo que yo -muy en mi papel profesional - respondí que no, porque de esa manera estaría alterando un registro arqueológico que alguien podría querer estudiar en el futuro, o algo por el estilo. "Sí, claro, por eso también", sentenció finalmente él. Al tratar de inquirir en ese también no tuve más respuesta que un por nada en particular, pero que mejor las dejase donde estaban. Es evidente que, en su interior, trataba de no ofender a los antiguos, aunque la versión oficial fuese por motivos patrimoniales, como tantas otras veces me ocurriría con mis interlocutores.

Como he planteado en otras páginas (Gil 2006: 210), los miedos que tradicionalmente los santiagueños situaban en el entorno de las ruinas arqueológicas han des- 
aparecido barridos por la modernidad, y el respeto a los chullpas se ha tornado en respeto al patrimonio arqueológico. Ya no actúan de determinada manera por no ofender a los antiguos, sino por conservar unas antigüedades en las que han puesto grandes expectativas de futuro con el turismo de por medio. Sin embargo, pese a que (casi) toda la comunidad ha incorporado este discurso oficial, la gente sigue manteniendo ciertas actitudes de respeto hacia los chullpas, e incluso de reverencia, pero sólo de puertas para adentro, en su cotidianidad. Valgan algunos ejemplos para ilustrarlo.

Cierto día de septiembre de 2001, Gonzalo y sus amigos Jorge C. (12 años), Héctor Q. (9 años) y Elmer B. (8 años) me condujeron hasta una gran estructura chullparia situada a orillas de Agua de Castilla. De camino al lugar me fueron contando de una moneda de oro (oro vivo) situada bajo un gran fragmento cerámico, tentándome a ver si yo me atrevería a cogerla. Intenté resolver con ellos por qué la moneda habría de seguir ahí sin que nadie — siendo vox populi su existencia- la hubiera cogido nunca, pero a ellos lo único que parecía importarles era ver si yo me atrevía o no. Finalmente hice ademán de meter el brazo en la chullpa para levantar la cerámica, y automáticamente me dieron el alto. Les pregunté si no querían que sacásemos la moneda, pero me dijeron que mejor otro día, que se había hecho tarde y era hora de volver a casa. En el camino de vuelta, manteniendo todos las apariencias de que no pasaba nada, se desarrolló una conversación muy significativa: insistiendo en su valor, uno de ellos confesó haber hurgado a veces en las ruinas comprobando la existencia de tesoros; otro exclamó de repente - y me temo que se arrepintió en el acto- que se iba a enfermar; los otros dos calificaron tal premonición de tontería y recriminaron al primero su acción argumentando que si todo el mundo hiciera lo mismo no vendrían más arqueólogos ni turistas a ver las cosas bonitas del pueblo. El cambio de valores resulta evidente. Los ideales de un futuro mejor basado en la explotación turística de las ruinas arqueológicas se han impuesto sobre el miedo tradicional a la ira de los antiguos. Sin embargo, aleccionando a los niños por uno u otro lado, el caso es que se pretende lograr que éstos se mantengan alejados de las ruinas, aunque muchas veces la lección no surta efecto.

Una situación similar volvió a repetirse días más tarde. Había subido con un grupo de alumnos y profesores a la chacra de papas que el Núcleo Educativo cultiva en la falda del cerro Lliphi. Terminada la siembra, la vuelta a casa se desarrolló de manera desperdigada, cada uno a su ritmo. Yo regresé con Gonzalo, Jorge, Novelio V. y Ricardo T. (ambos de 12 años). Tomamos un camino por encima de Agua de Castilla, saliendo a media altura de esa colina donde se emplaza el santuario del Señor de Quillacas. Ahí, entre el santuario y el acantilado, me señalaron una gran laja de piedra donde la comunidad celebra costumbres para las fiestas de Santiago Apóstol (25 de julio) y el Señor de Quillacas (14 de septiembre). Con premeditación y alevosía, ellos se pararon a descansar en el lugar, hablándome de que bajo la piedra se esconde un tesorillo de "plata de los antiguos" (plata viva, por así llamarla); que por levantar y mirar no pasa nada, pero que el Señor de Quillacas castigaría con terribles sufrimientos a quien osare robarlo. Después del episodio de la chullpa, yo no los tomé en serio, pero ante su insistencia nuevamente hice intención de mover la piedra y mirar. Una vez más me dieron el alto, esta vez con la excusa de que el resto nos estaría esperando en la escuela. Por un lado, no hay que olvidar que dicha colina queda fuera de lo que ven- 
dría a ser el perímetro de seguridad de la comunidad, integrada en ese espacio salvaje del cerro dominado por entidades tutelares $-\mathrm{y}$ en este sentido los santos funcionan como tales- que, si se enfadan, pueden volverse peligrosas ${ }^{15}$. Por otra parte, es cierto que bajo la laja de piedra hay algo, aunque no pertenece a los antiguos sino a este santo patrón: terminada la fiesta en el santuario, y mientras que la comunidad regresa al pueblo, parte de los especialistas rituales acuden a este lugar a ofrecer ch'allas y sahumerios y a depositar bajo la piedra el dinero recolectado durante la celebración, que días después pasará a retirar el sacristán (Gil 2010: 274). En cualquier caso, el cuento serviría para mantener a los niños alejados de un espacio ceremonial, igual que antes señalé al hablar del recinto de la iglesia.

Volviendo a la cuestión del miedo disimulado a los chullpas, regresemos a las ruinas de Laqaya. En la plaza central de Bajo Laqaya (sector de época Inca) se encuentra una "caja" o pozo revestido en piedra cuya función original no ha podido ser determinada con exactitud por encontrarse muy perturbado (Nielsen 2006: 80, ver también p. 78, fig. 6); seguramente un pozo de ofrendas en el contexto de rituales comunitarios en el espacio ceremonial de la plaza. Una plaza en la que, precisamente, las comunidades de Santiago y Santiago Chuvica sellaron su alianza — por así decirlocon el equipo arqueológico que desde 1996 se ocupó de los trabajos de excavación, prospección y análisis de materiales, además de proyectar la puesta en valor del yacimiento; un "encuentro ritual" en el que se contaron historias de los chullpas, se les presentaron diferentes ofrendas y se les pidió protección para el buen desarrollo del proyecto conjunto (Nielsen, Calcina y Quispe 2003: 374). Dicho de otro modo, se les pidió protección, pero también permiso para las labores arqueológicas e incluso perdón por perturbar su tranquilidad ancestral. Lo mismo sucedió nuevamente en octubre de 2004, cuando el sitio adquirió la categoría de Monumento Histórico, con sacrificio de llamas, ch'allas, discursos, danzas y ejecuciones musicales y banquete comunitario (Nielsen 2006: 86). En este sentido, ambos eventos sirvieron para que los comunarios de Santiago se reconciliaran con sus chullpas, al empezar los trabajos arqueológicos en el yacimiento y al darlos por terminados. Pero aún podría irse más allá y afirmar que a través de estos pagos compensatorios los santiagueños ponían un punto y seguido en su relación con los chullpas de Laqaya: las ruinas perdían su significación tradicional de espacio del miedo y, en aras de los mitos del turismo, se convertían en escenario del progreso. Así, la gente dejaba de temer a los chullpas... al menos oficialmente. Ahora bien, a juzgar por lo visto hasta aquí, ¿a todos ellos o sólo a los habitantes de Laqaya? Más aún, ¿̇realmente se perdió el miedo a los chullpas de Laqaya? Yo "descubrí" esta "caja" en 2001 y desde entonces no dejé de revisarla en cada campaña de trabajo de campo, observando siempre el mismo contenido: un cráneo y varios huesos (evidencia material de los antiguos), hojas de coca y cigarrillo. Esto es, aunque se dice que los chullpas ya no dan miedo, se les hacen ofrendas recurrentes a fin de apaciguarlos.

\footnotetext{
15 A este respecto, simplemente señalar que todas las entidades tutelares andinas presentan una doble cara, positiva y negativa, bondadosa o terrible dependiendo de las situaciones y de las relaciones de reciprocidad que se establezcan con ellas. Es ésta una vertiente más de eso que los antropólogos han llamado siempre "el principio de dualidad andina", considerado como uno de los rasgos compartidos por todos los pueblos de los Andes, de ayer a hoy.
} 
Por efecto de todos estos cambios de valores, los chullpas se han transformado en meros restos humanos de otro tiempo histórico. Cabría pensar que, en tanto que la gente (dice que) ya no cree en ellos, han perdido su poder. Pero nada más lejos de la realidad cotidiana. Veamos otro ejemplo.

A fines de noviembre de 2004 coincidí en Santiago con el arqueólogo argentino Axel Nielsen, un viejo amigo que desde 1995 viene trabajando en la región. Charlando sobre creencias locales en torno a las ruinas, me contó cómo tiempo atrás, y avisados por un vecino, su equipo había realizado una intervención rápida (un rescate, en el argot arqueológico) sobre unos restos aparecidos en la torrentera por efecto de la erosión: fragmentos cerámicos y algunos huesos. Al terminar el trabajo, este vecino quedó encargado de guardar el material hasta la próxima campaña, pues los arqueólogos estaban ya por irse en aquella ocasión. La siguiente vez que volvieron a Santiago, solicitaron a este vecino los restos para proceder a su estudio, pero él confesó haberlos botado nuevamente al basurero. Al poco de tenerlos en su casa, dijo, él se había empezado a sentir "raro", y su padre había enfermado. Le entró miedo y decidió que lo mejor sería deshacerse de aquello que consideraba era la causa de sus males. Al parecer, alejado el foco de peligro, él no tardó en volver a estar "normal", y su padre empezó a mejorar. Quien quiera, que entienda.

Por cerrar este punto mencionaré un último episodio relacionado con los juegos infantiles y los miedos disimulados en el entorno del wayco, que ilustra una vez más cómo los objetos antiguos, y más los restos humanos, siguen despertando recelos entre los santiagueños. A fines de septiembre de 2001 Ricardo T. (12 años) se ofreció a mostrarme un tojolol (cráneo) que había encontrado cerca de su casa, en el perfil erosionado de la torrentera. Acudí a verlo en su compañía y la de otros chicos, interesados por resolver cómo había llegado hasta allí y, de manera discreta, a quién habría pertenecido. Muy a grandes rasgos les expliqué cómo la erosión puede alterar un registro arqueológico y así sacar a la luz los huesos. Rápidamente dedujeron que, estando de por medio lo arqueológtico, serían restos antiguos, y por tanto sería un cráneo de chullpa, aunque por no aparecer en ningún chullpar, también podría no serlo, lo cual aparentemente les tranquilizó. Quisieron sacarse fotos; Jorge C. (12 años) quería retratarse con el cráneo, pero al mismo tiempo le daba reparos. De última, para no tocarlo directamente se sirvió de un cartón hallado en la basura a modo de bandeja, posando así orgulloso para la foto. Nuevamente, un miedo disfrazado y una situación de potencial riesgo ante el que no dejan de tomarse precauciones, tanto ideológicas como profilácticas.

\section{AL ANOCHECER, EN CASA ESTÉS}

La noche representa en términos universales un momento peligroso, cuajado de peligros y de seres (reales o fantásticos) que aprovechan la oscuridad para cometer sus desmanes. Por eso siempre nos han dicho que al anochecer es mejor estar ya en casa o, en todo caso, desconfiar de los extraños.

En Santiago anochece pronto, en torno a las 19:00 horas, momento en que los hogares pasan a disfrutar de sus únicas dos horas de luz eléctrica al día. De repente, las calles quedan prácticamente desiertas, y los pocos comunarios que por ellas tran- 
sitan es como si perdieran los modales y la educación: caminan deprisa, procurando esquivar a los otros, y si acaso se cruzaran con alguien ninguno saluda, o lo hace muy tímidamente y acto seguido aprieta el paso. En la comunidad todos se conocen, pero la noche es traicionera, y aquel que se cruza en mi camino podría no ser realmente quien aparenta ser. Por eso, es mejor no llamar su atención, no hablarle; simplemente hay que dejarle pasar y que cada cual siga su camino, porque si finalmente resultara ser una alteridad terrible con toda seguridad que vendría tras nosotros. Éste fue precisamente el proceder de Jaime García Mamani en cierta ocasión que creyó encontrarse con dos condenados, y que al contarme la historia días después todavía se estremecía de miedo:

El día viernes fui a Colcha. Voy a Colcha en moto y vengo aquí caminando. Subí ese cerro de Mañica, llegué a Chuvica ${ }^{16}$. A las seis y media estoy pasando el cementerio [de Chuvica]. En Laqaya estoy pasando a las siete. Y de ahí a aquí se me hizo largo. Largo de Laqaya a aquí. Estoy pasando... o sea que es esos hoyaditos, ¿no? ¡Pero qué tenebroso! [En] El cementerio [de Chuvica] no he tenido miedo, [En] Laqaya no he tenido miedo. Pero de verdad, de esa pampa a aquí... Aquí, más o menos. Terrible. 'Pfiuff, pfiuff'. El cuerpo desde hace rato... tenía la carne medio dura. Parece que me quedo parado, parece que me estoy afectando yo mismo. 'Pchisss'. Un aire nada más está sonando por estas peñas. Un aire nada más está sonando. Como hay tantos aires ahí en esos $\operatorname{cerros}^{17} \ldots$ Ya últimamente me puse a cantar. Ni silbando. Ni el silbido es perfecto, ni el cantar es perfecto. Más vengo vengo, cuando en el camino... iZás! Pasan dos terráqueos. Ya, eso era gente. No me han saludao. Vengo más aquí cantando. Estoy cantando tonteras, mejor canto canción de Evangelio. Empiezo a cantar canción de los Evangelios. Ya estoy cantando. Aún así, el corazón se me sale, porque ya es cantar. O sea, es un lugar muy tenebroso. Yo he hecho así el camino. Nunca me pasa nada, pero aquí, de por sí, me lleva el miedo. Tenía miedo, y aquí llegué a las ocho. Tarde. Yo tengo miedo de pasar por el cementerio y me vine por aquí; por el río subí. Es que estaba ya por la iglesia, también he tenido miedo de subir. He tenido miedo de la iglesia. Dicen que la iglesia, antes, también sería cementerio. He visto yo entierros de ese cementerio. Donde está la pila, cavas, ahí están: huesos, de restos humanos. El mismo cementerio... o sea, la misma iglesia era cementerio $^{18}$. Entonces yo tuve miedo de venir hasta acá. Sí, es un lugar muy especial. Pero no hay que asustarse, [pues] es aquí cerquita. (Jaime Mamani García, 35 años. Santiago, 10/09/2001).

Jaime Mamani García es oriundo de Llica (Daniel Campos, Potosí), aunque, por los años que lleva ejerciendo de profesor en distintos núcleos educativos de Nor Lípez, dice sentirse lipeño de adopción. Gusta de conocer las tradiciones de las comunidades que le acogen, especialmente las que tienen que ver con diablos, fantasmas o sucesos paranormales, temas que le atraen desde siempre, aunque confiesa que un poco de miedo sí le producen a veces. Sintetizando su relato, el profesor Jaime ca-

${ }^{16}$ Colcha, Mañica y Santiago Chuvica son comunidades vecinas en dirección sur, en la ruta que desde Uyuni llega a Santiago pasando al costado del cementerio, el campo de fútbol, la posta sanitaria y bordeando la iglesia; esto es, atravesando esa pampa que antes señalé como espacio peligroso y escenario de diversos miedos tradicionales y modernos.

${ }^{17}$ Recuerde el lector lo mencionado anteriormente acerca de la bondad y la maldad de los vientos andinos, y la posibilidad de enfermar por culpa de un mal aire.

${ }^{18}$ Efectivamente, las lápidas del actual cementerio de Santiago remontan tan sólo hasta la década de 1940. "Antes", dicen, la gente se enterraba en la iglesia, y también "más antes", "en tiempos del coloniaje". 
minaba de regreso a Santiago, solo, al atardecer, y la noche le sorprendió de camino. Pasó por delante de un cementerio ("miedo" a los muertos) y por delante de unas ruinas arqueológicas ("miedo" a los chullpas), y aunque confiesa no haber sentido temor, empezó a autosugestionarse. Llegando a Santiago, en la pampa, se cruzó con dos personajes que no le saludaron y a los que él tampoco dijo nada; al contrario, a raíz del encuentro decidió empezar a cantar "canción de los Evangelios" tratando de apartar de sí cualquier peligro y buscando protección en $\mathrm{Cristo}^{19}$. Ni siquiera atravesando el cauce de Agua de Castilla se liberó de sus temores, que no hicieron sino aumentar a medida que cruzaba a través de esa pampa peligrosa que se extiende justo al límite del espacio social de la comunidad. Al preguntarle cómo eran aquellos dos personajes me respondió: "Dos terráqueos ${ }^{20}$. Callados. Como flotando andaban, muy sigilosos". "Terráqueos", unas entidades que me definió "como almas en pena, como almas condenadas". Así, lo que aquella noche asustó al profesor Jaime fueron dos condenados, o al menos eso fue lo que él creyó.

De acuerdo con el folklore de buena parte de los Andes, los condenados serían, efectivamente, el equivalente a las almas en pena cristianas, que antes de pasar al mundo de los muertos deben permanecer en éste purgando sus pecados, generalmente relacionados con un amor desmedido o inapropiado, o con el egoísmo y la avaricia; también el suicida se condena, e incluso aquel que sufrió una muerte especialmente violenta queda errante en este mundo. Por haber amado o haber sido amando en exceso, por haber ambicionado bienes y no haber querido compartirlos, señala A. Ortiz (1986: 212), el alma de la persona se condena, y como no puede abandonar este mundo, pena por los caminos y los despoblados causando estragos. De aspecto monstruoso aunque con disfraz humano, el condenado habita en las afueras de los pueblos, saliendo en busca de sus víctimas al atardecer y durante la noche. "No es un ser excluido en absoluto; no es un demonio —matiza J. M. Arguedas (1960-61: 197)—; es un sub-humano que sufre y destruye como medio de encontrar su redención ${ }^{21}$. Arroja fuego por la boca y sufre un hambre voraz a consecuencia de tener un agujero en la garganta que le impide tragar la comida que su víctima vanamente le ofrece para intentar huir de él. Encarna la idea de una existencia patética y miserable, y cumple una función de control social que nos avisa de lo desproporcionado que puede llegar a ser el castigo impuesto a nuestras faltas. Por eso Arguedas (1960-61: 209-210) interpreta que los cuentos de condenados no sólo sirven para infundir temor en lo relacionado con la trasgresión de las normas sociales más elevadas, sino también para advertir a niños y adultos de los riesgos que se ocultan tras la mera imprudencia y el tentar a la suerte.

Por despejar dudas acerca de la presencia de condenados en Santiago, dediqué parte de mis campañas de campo de 2001 y 2002 a indagar sobre este personaje,

\footnotetext{
${ }^{19}$ No deja de ser significativo que el profesor Jaime empezara a entonar "canción del Evangelio" al sentirse asustado y en peligro, pues, hasta donde yo he sabido, no pertenece a la reducida comunidad evangélica (pentecostal) de Santiago.

${ }^{20}$ Contrasta esta alusión a "dos terráqueos" por parte del profesor Jaime, con la consideración generalizada de interpretar la figura del condenado como una manifestación de "vida extraterrena" (Arguedas 1960-61: 199).

${ }^{21}$ A este respecto de los condenados, Cf. también la tipología compuesta por este mismo autor a partir de los cuentos por él recogidos en el valle del Mantaro (Perú) (Arguedas 1953).
} 
obteniendo así algunas informaciones relevantes que me permitieron entender mejor los miedos y algunas prácticas cotidianas asociados a esta pampa a la que vengo prestando atención.

Erasmo Condori Ticona - a quien ya introduje páginas atrás- es un gran conversador, y uno de mis interlocutores más pacientes y detallistas. Maestro jubilado, encargado del registro civil y parroquial, sacristán de una iglesia a la que el sacerdote sólo acude muy de vez en cuando, es a la vez conocedor de yerbas y otros remedios, y entendido en materia de costumbres; desde los 25 años, ha pasado varios cargos cívicos y rituales, llegando a ser una persona de prestigio dentro de la comunidad. Le encanta hablar sobre los chullpas, los tiempos antiguos o la historia de Santiago, aunque sobre otros asuntos no se muestre habitualmente tan locuaz. Sobre el condenado en concreto me contó una vez lo siguiente:

Es una persona que cuando muere vuelve a vivir, ¿no ve? Eso, a eso llaman condenao. No se le puede matar de ninguna forma, no más hay que huir de él. No. Hay que saber, pues. Pero yo creo que así debe morir, porque ya no existe con este tiempo. ¿Se da cuenta no más qué será? Debe ser para los cuentos no más, porque si no existiría pues hasta ahora, ¿no ve? No hay sino cuento, porque si habría de verdad condenao, entonces debe existir. No hay tal condenao.

[...] Lo único, dicen, no pasa por el río [Agua de Castilla]; aunque poquita agua que está corriendo, no pasa, ahí se salvaban, dice. Al otro lado del río está la gente. Entonces, no puede pasar el río, y ese río se hace grande, dice, para el condenao, parece que por poquita agua que sea. Por eso no pasa, dice, no pasaba del río al otro lado. Ahí se salvaban, que si no era terrible; dicen que el condenao consumía a la gente.

La gente pasaba el río, y después al otro lado ya está tranquila. El condenao está correteando, dicen, por el río, para arriba, para abajo, queriendo pasar. Así dicen que es verdad para el cuento.

Pero la gente que pasaba, tenía que volver. Esperaban que el condenao desaparezca, pues, para poder regresar, porque tienen su casita aquí y pasaban el río al otro lado. Con poquito río que esté corriendo, ya no pasa el condenao. No pasa el agua. O sea, que la gente está al otro lado a salvo, que ya no le come el condenao. Así ya no pasa. (Erasmo Condori Ticona, 60 años. Santiago, 08/09/2002).

Como tantas otras veces, don Erasmo anula los miedos tradicionales y niega a las entidades terribles causantes de ellos. En todo momento rebaja al condenado al mundo de los cuentos, de los rumores. Incluso resta valor a la precaución de no cruzar el cauce de Agua de Castilla — pues al otro lado se eleva ya el espacio salvaje del cerro Lliphi-, apostillando que "es verdad para el cuento" y por ende considerándolo una mera superchería. Sin embargo, como suele decirse -y nunca mejor dicho en este caso-, "cuando el río suena... agua lleva". Recordemos que el profesor Jaime trató de esquivar a sus dos supuestos condenados caminando por el río hasta ingresar ya en la pampa que se extiende frente a la iglesia. Pero más llamativo resulta el hecho de que en alguna una ocasión - y sin prestarle mayor atención hasta conocer el dato de boca de don Erasmo- he podido observar a gente mayor mirar a ambos lados del curso de agua antes de atravesarlo, igual que si atendieran a las dos direcciones de una calle con tráfico rodado antes de cruzarla. Pudiera ser casualidad. Pudiera ser que el etnógrafo a veces se empeña en sacar punta a todo lo que la gente hace. Pero ¿por qué no pudiera ser éste un acto mecánico cotidiano en aquellos que fueron criados y educados en la tradición de lo que don Erasmo se empeña en considerar meros "cuentos"? 
Ahora bien, si Agua de Castilla — «aunque poquita agua que está corriendo» habría de suponer una barrera infranqueable para el condenado, ¿por qué el profesor Jaime siguió temiendo a los dos personajes de su relato aún estando ya del otro lado? La respuesta me la proporcionaron dos dibujos del taller escolar "Mi comunidad" desarrollado en $2001^{22}$; en los que se ubicaba a un enigmático personaje en esa pampa que se extiende entre el borde oriental de la comunidad y este cauce de agua.

La composición de Marsia N. (12 años) resulta naíf(figura 1) y su explicación del personaje de tamaño desproporcionado que sitúa cerca de los campos de fútbol (figura 1, detalle), inocente y sincera: me dijo que era el "fantasma" que, según cuentan, ataca a quienes andan por la pampa durante la noche; añadió que ella no se creía esa historia, que seguramente fuese tan sólo "para asustar", pero que le había parecido "simpático" incluirlo en su dibujo.

Agustín Orlando B., que a pesar de sus 19 años recién cumplidos aún asistía al colegio, optó por una proyección tridimensional del espacio urbano, sobre la que asimismo volcó otro tipo de información adicional (nombre de calles, identificación de elementos arquitectónicos y paisajísticos, e incluso alineación de los equipos de fútbol en el terreno de juego) (figura 2). En su dibujo aparecen dos personajes, uno en la plaza, junto a una bicicleta, que no identificó como alguien en particular; y otro entre la iglesia, un calvario y el generador eléctrico. Cuando le pregunté por este último, de apariencia grotesca, desgreñado, brazos en alto y de cuyas manos parece chorrear sangre (figura 2, detalle), sonrió sardónicamente, me miró con complicidad y me especificó: "No sé, como un monstruo. Dicen que anda por ahí, a la nochecita. Como una aparición, dicen. Te agarra y te devora. Pero no vamos a creer ese cuento, ¿no ve?".

Condenados, fantasmas, aparecidos, monstruos, "cuentos", historias "para asustar". El caso es negar la causa del miedo aunque éste siga habitando en nosotros. Pero claro, los jóvenes de Santiago no tienen miedo de aquello que, supuestamente, según se dice, no existe. Es más, tanto para Marsia como para Agustín Orlando el arquetipo del condenado resultó ser un completo desconocido; ahora bien, en su imaginario del horror no faltaban vampiros, hombres-lobo o extraterrestres, de cuya existencia real ni ellos ni sus amigos dudaban. Qué paradoja bastarda de la Modernidad y la Globalización. Sin embargo, la esencia de ese condenado que otrora asustó a sus mayores y que todavía hoy sigue asustando a algunos, pareciera seguir latente en este nuevo fantasma-monstruo: ataca y devora a quienes durante la noche están donde no deben, en la pampa, y además, seguramente, haciendo lo que no deben. Quizás por ello, para alentar el miedo y forzar así una conducta ordenada y decorosa entre niños y jóvenes, el nuevo condenado ha cruzado la frontera de Agua de Castilla y se ha instalado justo en el borde del espacio social de la comunidad, más próximo a la gente, para que su influencia sobre ellos resulte más efectiva.

\footnotetext{
${ }^{22}$ Los dibujos incluidos en este trabajo provienen del taller "Mi Comunidad", que organicé entre los alumnos del Núcleo Educativo en septiembre de 2001, una experiencia desde la cual pretendí acercarme a la percepción del espacio social de la comunidad entre niños y adolescentes. Desde aquí, mi agradecimiento a la Dirección y a todo el cuadro docente, por las atenciones dedicadas a mi persona y el tiempo prestado a mis talleres con los alumnos en cada una mis estancias de trabajo de campo en Santiago desde esta primera vez.
} 


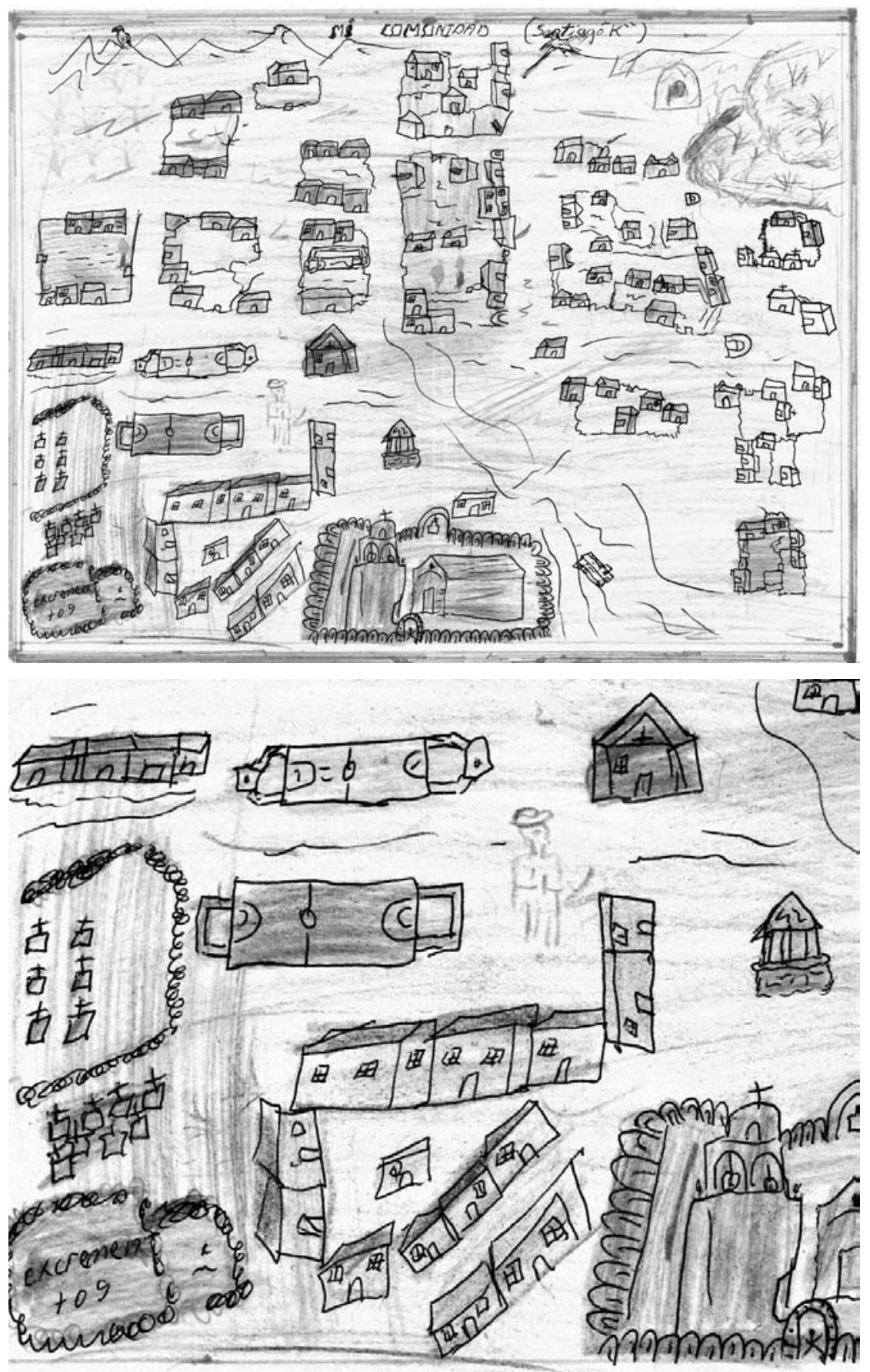

Figura 1.-Mi comunidad (Santiago "K"). Marsia N., 12 años. Santiago, 2001. A la izquierda, junto a las canchas de deporte, representación de un personaje asimilable al condenado (detalle). 

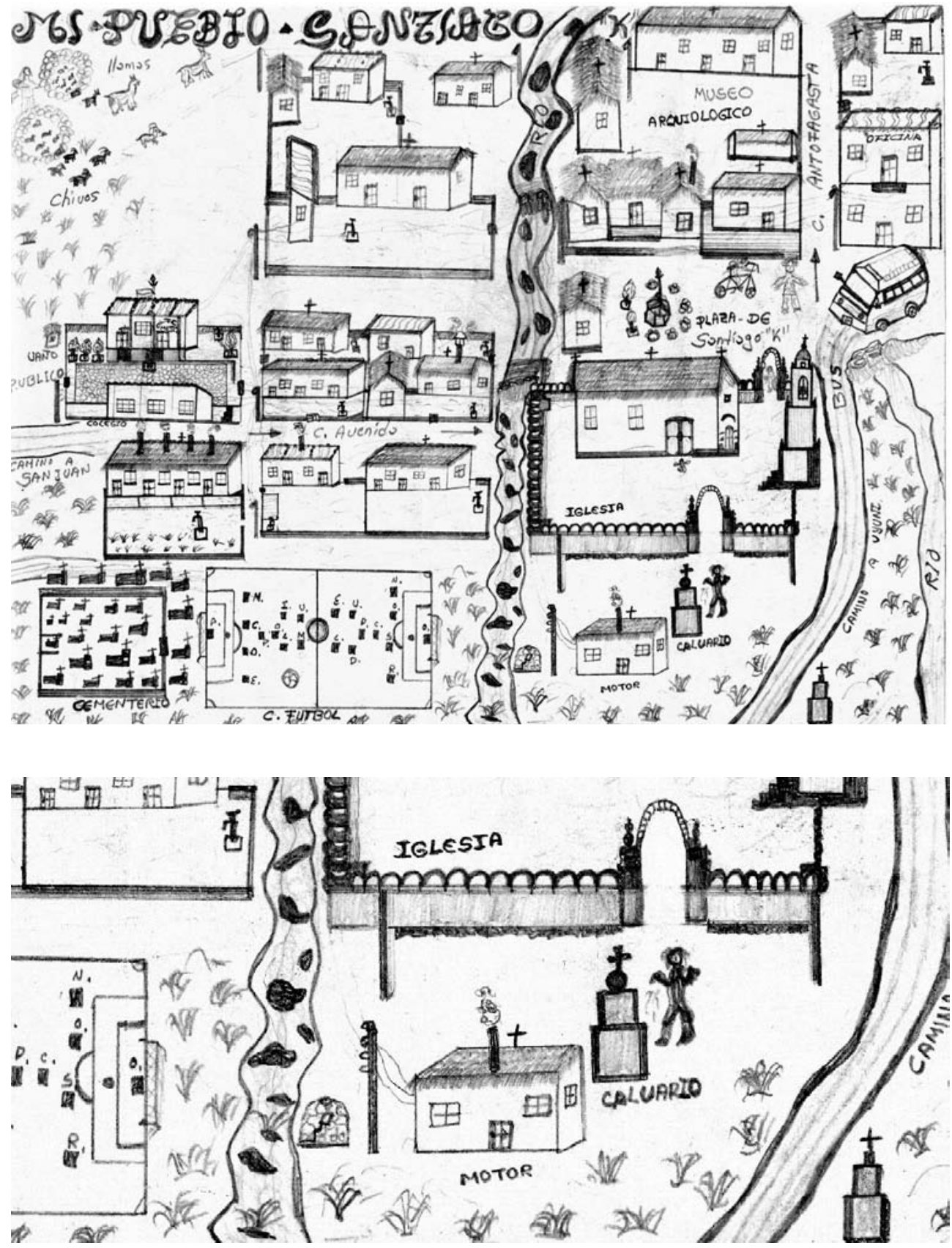

Figura 2.-Mi pueblo - Santiago. Agustín Orlando B., 19 años. Santiago, 2001. Abajo a la derecha, junto al calvario anexo al "motor de la luz", representación de un personaje asimilable al condenado (detalle). 
Y lo cierto es que, por un motivo o por otro, esta pampa cuajada de miedos negados imprime carácter en la cotidianidad de los santiagueños. A cuántos partidos de fútbol he asistido que empezaban a la tardecita pero se prolongaban más allá del ocaso - terminados de jugar prácticamente a oscuras, pues en Santiago no hay alumbrado público-, y cuántas veces el encuentro se detenía por un tiempo exagerado cada vez que la pelota rodaba fuera del campo, hasta la pampa o el cementerio. A nadie le asustan esos espacios, pero los de un equipo dicen que vayan a recuperarla los del otro y viceversa... todos apelan al chutador desmesurado para que sea él quien se encargue de ello, y él, claro, se escaquea... los unos empiezan a dudar del coraje de los otros, y hasta el público acabará jaleando a los jugadores en estos mismos términos. Finalmente alguien se atreve a recuperar la pelota y el encuentro se reanuda. Quizás, seguramente, no hay nada que temer, pero se impone "el por si acaso".

De la misma manera, aquellos que se ven obligados a salir de sus casas a horas poco recomendables prefieren dar todos los rodeos del mundo con tal de no salirse del casco urbano, por más que atravesando este espacio pudieran atajar su camino. Sólo al Corregidor, encargado de conectar y desconectar el "motor de la luz", no le queda más remedio que cruzar esta pampa todas las noches. Lo hace enfundado en su chamarra, silencioso, ni siquiera alumbrándose con una linterna, el paso apresurado; en fin, que no es difícil asustarse ante su presencia por confundirlo con un espectro. Y qué curioso: una pampa hasta cierto punto prohibida que a la noche es atravesada por el Corregidor (autoridad civil de la comunidad) y guardada por una entidad terrible (velador moral). ¿Será este condenado, en cualquiera de sus manifestaciones, un cuento como dicen, un asustachicos que sigue asustando también a los grandes? Qué cada cual consulte a sus miedos.

\section{CONSIDERACIONES FINALES}

Ni que decir tiene que el miedo acompaña al ser humano en su devenir histórico y cultural entablando con él un diálogo permanente; es protagonista constante en las historias de vida y, de un modo u otro, más o menos velado, se muestra omnipresente en la vida cotidiana, más todavía en épocas de crisis. Para vivir en sociedad hay que acatar unas normas de conducta que canalicen nuestros impulsos y nuestras emociones. El aprendizaje de éstas, la mayor parte de las veces, y sobre todo durante la infancia, va ligado a la instrucción en determinados miedos. Miedos que se aprenden por condicionamiento, por experiencia directa, por imitación y/o por transmisión de información y asimilación de mensajes alarmantes. Por ello el abanico de miedos es infinito, multiplicándose por la manipulación de determinados resortes de nuestro inconsciente bajo según qué circunstancias (González 2007: 12-13, 198 y ss.; Marina 2006: 101-103). Por lo mismo, los miedos resultan tan maleables, tan mutables.

El miedo es libre, y resulta difícil poder trazar una etnografía detallada del Miedo (con mayúsculas) en el conjunto de cualquier comunidad desde la óptica de su vida cotidiana. Si la cotidianidad constituye un tipo de realidad social ordenada, coherente pero a la vez subjetiva, y en buena medida particular para cada individuo, familia o grupo social, lo complejo es poder llegar a aprehender su núcleo duro. Más bien podremos tan sólo, desde la observación y el análisis de los actos individuales y los 
valores personales y colectivos, alcanzar a entender la conciencia que se tiene del orden que rige dicha realidad cotidiana y, por ende, de los peligros que lo acechan; una realidad cotidiana, por complicar un poco más las cosas, capaz de moverse por distintas esferas de realidad espacio-temporales que convergen en el "aquí y ahora" (Berger y Luckmann 1997: 36-46). Por ello, he preferido enfocar estas páginas contextualizando escenarios del miedo y entidades terribles en relación directa con la actividad cotidiana de los santiagueños, pues de ese modo me ha parecido más fácil acceder a un abanico tan notable de divergencias entre el dicho y el hecho como el presentado en la muestra de análisis. Mientras que de manera consciente y deliberada se niega el escenario y/o el causante de esos miedos tradicionales -hoy por hoy supersticiosos y demodé-, subconscientemente seguimos albergando ciertos temores que quedan al descubierto a partir de nuestros actos rutinarios.

La construcción de unos entornos cotidianos y la definición de unas prácticas rutinarias es lo que nos permite sentirnos ubicados y seguros en el mundo que habitamos. Sin embargo, la Modernidad primero y a continuación la Postmodernidad, han trastocado fuertemente las estructuras de pensamiento y los sistemas de valores tradicionales, forzando con ello un cambio cualitativo de la comunidad - esa imposición de los ideales de progreso sobre el miedo, como señalé-. El mundo que nos rodea cambia a un ritmo mucho más rápido del que podemos seguir, se tambalean las certidumbres, se impone una lucha entre el olvido y la rememoración, entre la Tradición y la Razón, y todo ello se va reflejando en la vida cotidiana (Duch 2002: 105120). La distancia entre los mundos de los mayores (tradicional) y los jóvenes (moderno) aumenta por momentos, y desde el presente se descalifica en cierta medida el pasado, al que se considera atrasado y vencido. En lo que a miedos se refiere, se considera a los mayores demasiado asustadizos, y se tildan de superchería sus miedos tradicionales; tanto que al final ellos mismo acabarán por entrar en ese juego, y el discurso oficial irá transformándose poco a poco hasta negar su existencia. Y sin embargo, esos miedos y sus causantes seguirán entre nosotros, por más que a través de diferentes narrativas sociales intentemos "domesticarlos".

Aún en el hipotético caso de que la fuente de un miedo fuera neutralizada por completo, en el subconsciente colectivo siempre va a permanecer vivo un poso, generalmente impreso en los espacios de memoria. Por eso, aunque aparentemente los santiagueños hayan apagado el miedo a los chullpas, mantienen ciertos comportamientos que denotan dicho rescoldo: el respeto a las ruinas arqueológicas y el miedo de los padres a que sus hijos jueguen en el wayco. En el primer caso, el miedo a poder contraer la enfermedad de la chullpa por hurgar en las ruinas a la busca de objetos antiguos ha sido desplazado por una preocupación por mantener intacto un registro arqueológico que se piensa atraerá al turismo, que a su vez devendrá en progreso y prosperidad económica para la comunidad. En el segundo caso, la incertidumbre ante la posibilidad de que en el wayco aparezcan restos arqueológicos queda disimulada por el temor a que los niños sufran algún accidente en el basurero. Sea por las razones que sean, el miedo sigue ejerciendo su influencia sobre estos espacios considerados salvajes en el entorno inmediato del pueblo.

Algo similar ocurriría con el traslado del espacio de actuación del condenado, que antes se mantenía más allá de Agua de Castilla, pero que ahora parece haber cruzado el río aproximándose a Santiago y transformando en espacio del miedo entornos 
que antes no lo eran: el descampado entre la iglesia y el "motor de la luz", la pampa frente a la posta sanitaria, y el campo de fútbol en asociación al complejo del cementerio. Causa o consecuencia de ello, la propia figura del condenado también ha mutado, acercándose a la idea del alma en pena o el muerto viviente, algo en lo que, sin duda, la ficción cinematográfica y eso que podría llamarse "tétrico folklore de cementerios" han ejercido cierta responsabilidad.

Al mismo tiempo que construimos nuestra cotidianidad debemos ser educados en ella - generalmente mediante la repetición de rutinas que al final se nos graban en el subconsciente y se transforman en acciones mecánicas-, de tal modo que lo cotidiano se convierta en lo ordenado, lo correcto, la costumbre, tanto más rígida cuanto más tradicional sea la sociedad. Así, el ideal de vida en comunidad pasa por mantener un orden (moral) dentro de lo cotidiano; un orden cotidiano que nos aporta seguridad pero que resulta extremadamente sensible a las contingencias y los procesos de cambio. Por eso quizás la figura del condenado ha mudado de escenario y esencia, sembrando nuevos miedos en viejos espacios que se han visto asimismo transformados en sus usos cotidianos, porque la cotidianidad de la comunidad también ha mutado, porque su espacio social se ha ampliado y porque el sistema de valores (sensu conjunto de hábitos adquiridos por la sociedad) también ha experimentado cambios notables.

Recopilando testimonios orales y gráficos, he pretendido en estas páginas establecer una correspondencia entre la vida cotidiana —enfrentando discurso oficial y prácticas comunes- y los espacios del miedo y de las entidades terribles que asedian a la comunidad de Santiago. Unos espacios móviles y unas entidades mutables que no hacen sino dejar constancia de que el ser humano nunca terminará de encontrarse seguro en su mundo, presa de un círculo vicioso donde los miedos vencidos son pronto reemplazados por nuevos miedos a vencer. Como seres humanos, por más que nos empeñemos en ellos, nunca alcanzaremos a dominar la totalidad del mundo que nos rodea, y eso, por más que nos cueste asumirlo, por más que intentemos negarlo, disfrazarlo, reprimirlo, desplazarlo o proyectarlo, nos aterra.

\section{BIBLIOGRAFÍA CITADA}

Arguedas, J. M. 1953. "Folklore del valle del Mantaro. Provincias de Jauja y Concepción". Folklore Americano 1: 101-293.

Arguedas, J. M. 1960-1961. "Cuentos religiosos-mágicos quechuas de Lucamarca”. Folklore Americano 8-9: 142-216.

Berger, P. L. y Luckmann, T. 1977 [1966]. La construcción social de la realidad. Buenos Aires: Amorrortu.

Bernand, C. [Muñoz-Bernand, C.]. 1986. Enfermedad, daño e ideología. Antropología médica de los Renacientes de Pindilig. Quito: Abya-Yala.

Díaz G. Viana, L. 2003. El regreso de los lobos. La respuesta de las culturas populares a la era de la globalización. Madrid: CSIC.

Duch, L. 2002. Antropología de la vida cotidiana. 1. Simbolismo y salud. Madrid: Trotta.

Gil García, F. M. 2005. "Batallas del pasado en tiempo presente: 'guerra antigua', civilización y pensamiento local en Lípez (Dpto. Potosí, Bolivia)". Bulletin del IFEA 34 (1): $1-24$. 
Gil García, F. M. 2006. "Cuando vengan los turistas... Ruinas arqueológicas, turismo y expectativas locales de futuro en Nor Lípez (Dpto. Potosí, Bolivia)". Textos Antropológicos 15 (2): 197-228.

Gil García, F. M. 2008. "Un pueblo sitiado. Miedos y entidades terribles en la construcción del espacio social de una comunidad surandina", en Fernández Juárez, G. y Pedrosa, J. M. (eds.), Antropologías del miedo. Vampiros, sacamantecas, locos, enterrados vivos y otras pesadillas de la razón: 145-196. Madrid: Calambur.

Gil García, F. M. 2010. "De casa al cerro pasando por la iglesia. El culto al Señor de Quillacas en una comunidad de Nor Lípez (Potosí, Bolivia)". Revista Española de Antropología Americana 40 (1): 261-286.

Gil García, F. M. 2014. "La cocina de los chullpas. Representaciones del pasado e identidades en el presente a partir de la alimentación en los Andes". Revista Española de Antropología Americana 44 (1). (En prensa).

González Duro, E. 2007. Biografía del miedo. Los temores en la sociedad contemporánea. Barcelona: Debate.

Marina, J. A. 2006. Anatomía del miedo. Un tratado sobre la valentía. Barcelona: Anagrama.

Nielsen, A. 2006. "Plazas para los antepasados: descentralización y poder corporativo en las formaciones políticas preincaicas de los Andes circumpuneños". Estudios Atacameños 31: 63-89.

Nielsen, A.; Calcina, J. y Quispe, B. 2003. "Arqueología, turismo y comunidades originarias: una experiencia en Nor Lípez (Potosí, Bolivia)". Chungará, Revista de Antropología Chilena 35 (2): 369-377.

Ortiz Rescaniere, A. 1986. "Imperfecciones, demonios y héroes andinos". Antropológica 4: 191-224.

Reguillo, R. 2000. "Los laberintos del miedo. Un recorrido para fin de siglo". Revista de Estudios Sociales 5: 63-72.

Reguillo, R. 2006. "Los miedos: sus laberintos, sus monstruos, sus conjuros. Una lectura socio-antropológica", en Pereira, J. M. y Villadiego, M. (eds.), Entre miedos y goces. Comunicación, vida pública y ciudadanías: 25-54. Bogotá: Pontificia Universidad Javierana.

Fecha de recepción: 11 de julio de 2014

Fecha de aceptación: 10 de octubre de 2014 